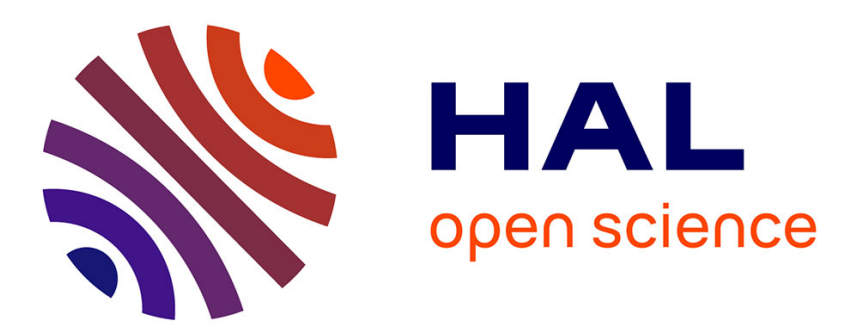

\title{
Evolution of the fresh water distribution in Nouakchott after the commissioning of the Aftout Es Saheli project
}

Isselmou A. Babah, Daniel Froelich, Mohamed F. Deida, Gérard Blake

\section{To cite this version:}

Isselmou A. Babah, Daniel Froelich, Mohamed F. Deida, Gérard Blake. Evolution of the fresh water distribution in Nouakchott after the commissioning of the Aftout Es Saheli project. Desalination and Water Treatment, 2015, 2015, pp.1-14. 10.1080/19443994.2015.1049957 . hal-01206298

\section{HAL Id: hal-01206298 \\ https://hal.science/hal-01206298}

Submitted on 28 Sep 2015

HAL is a multi-disciplinary open access archive for the deposit and dissemination of scientific research documents, whether they are published or not. The documents may come from teaching and research institutions in France or abroad, or from public or private research centers.
L'archive ouverte pluridisciplinaire HAL, est destinée au dépôt et à la diffusion de documents scientifiques de niveau recherche, publiés ou non, émanant des établissements d'enseignement et de recherche français ou étrangers, des laboratoires publics ou privés. 


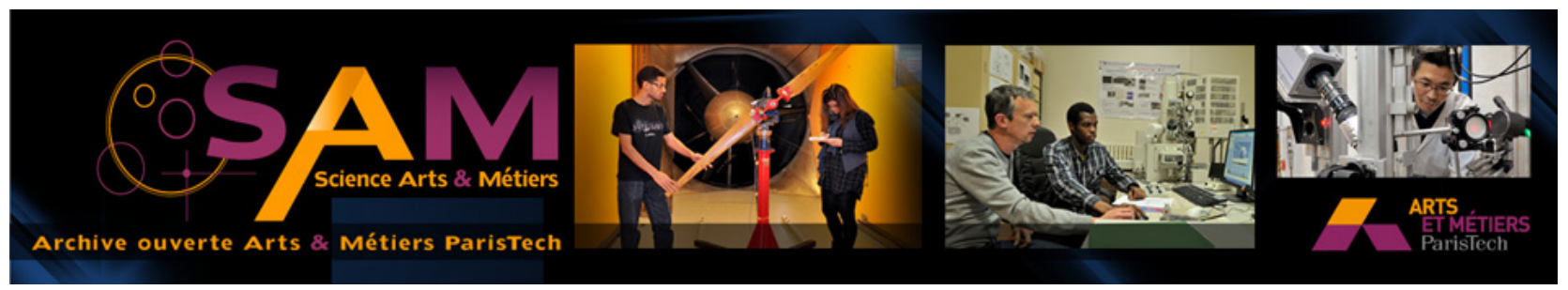

\section{Science Arts \& Métiers (SAM)}

is an open access repository that collects the work of Arts et Métiers ParisTech researchers and makes it freely available over the web where possible.

This is an author-deposited version published in: http://sam.ensam.eu

Handle ID: .http://hdl.handle.net/10985/10202

\section{To cite this version :}

Isselmou A. BABAH, Daniel FROELICH, Mohamed F. DEIDA, Gérard BLAKE - Evolution of the fresh water distribution in Nouakchott after the commissioning of the Aftout Es Saheli project Desalination and Water Treatment - Vol. 2015, p.1-14 - 2015 


\title{
Evolution of the fresh water distribution in Nouakchott after the commissioning of the Aftout Es Saheli project (water from the Senegal River)
}

\author{
Isselmou Ahmedou Babah ${ }^{a}$, Daniel Froelich ${ }^{b}$, Mohamed Fadel Deida $^{\mathrm{a}}$ \& Gerard Blake ${ }^{\mathrm{c}}$ \\ ${ }^{a}$ Faculty of Sciences and Techniques/UCME, University of Science, Technology and \\ Medicine, P.O. Box 5026, Nouakchott, Mauritania, Tel. +222 44617018; Fax: +222 452997 \\ ${ }^{b}$ Chambery National Higher School for Arts and Crafts (Ecole Nationale Supérieure d'Arts et \\ Métiers (ENSAM) de Chambéry), 73375, Le Bourget du Lac Cedex, P.O. Box 295, France, Fax: \\ $+33479253670$ \\ c University of Savoie/Chambery (Polytech'Savoie), Le Bourget du Lac Cedex BP 295, France
}

\begin{abstract}
Mauritania is characterized by an arid climate with limited water resources. Nouakchott has experienced tremendous growth, from a population of several hundred people in 1960 to over 700,000 in 2005 according to the National Statistics Office, this growth has generated abnormal pressure on core infrastructure, particularly for drinking water and wastewater management. The water needs of the population of Nouakchott were exclusively met by the excessive exploitation of Idini aquifer's well field. In late 2010, Mauritania began operating the Aftout Es Saheli project supplying the city with water pumped from the Senegal River. The aim of this paper is to present the evolution of the water situation in the city before and after the Aftout Es Saheli project, and to recommend ways to improve the management of this situation, especially in the peripheral neighborhoods. Our study focused on the water's availability and physico-chemical and bacteriological qualities in both poor neighborhoods supplied by a high-risk informal distribution system and affluent neighborhoods supplied by the network. In this context, we note that, despite the dilapidated distribution system, the start-up of Aftout Es Saheli and the progressive eradication of the informal system have significantly improved the covering of the population's water needs with an improving water quality.
\end{abstract}

Keywords: Aftout Es Saheli; Drinking fountains; Drinking water analyses; Total coliforms; Fecal coliforms; Sanitation

\section{Introduction}

The overall climate in the area studied is generally hot and dry throughout most of the year. The climate in Nouakchott is of the oceanic desert type, in this case Saharan Atlantic [1]. Indeed, in Nouakchott, the rainy season usually begins in late June, reaches its maximum in August and ends in September. The 
proximity of the ocean attenuates the Saharan nature of the climate. The total annual rainfall remains low and varies considerably from one year to the next. The low precipitation and significant evaporation due to the extreme heat make Nouakchott a hot and dry area. Consecutive decades of drought have accentuated the rarefaction of water resources in the city, making the problem increasingly acute. The rural exodus due to the drought, combined with intensive urbanization, has accentuated water needs, which were already considerable in the country's capital [2,3]. Indeed, the city has experienced tremendous growth, bringing its population from a few dozen families in 1960 to over 700,000 in 2007 and just under a million this year, causing the formation of slums around the city's urban core.

The objective of this research project was to analyze the evolution of the fundamental problems linked to the environmental and sanitary quality of water distribution in the city of Nouakchott. This study is part of a process to continuously improve the quality of the water abstraction and distribution system, in order to control and progressively improve water management and water quality in the city throughout the life cycle of the resource, i.e. abstraction (uptake), distribution and usage, as well as wastewater treatment.

In this paper, we will discuss the particular context of the availability of the resource prior to the Aftout Es Saheli project (supplying water from the Senegal River, near the city of Nouakchott located in an arid zone with very little rainfall and a high degree of evaporation). We will also discuss the quality of the distributed water, closely linked, prior to Aftout Es Saheli, to the informal water distribution modes used, based on physico-chemical and bacteriological analyses of representative samples taken in the city, and on a survey carried out with households in three pilot neighborhoods. We will then discuss the sanitation methods and the waterborne diseases observed in the city during this period.

Finally, we will present a summary of the current water quality situation and its availability after the commissioning of the Aftout Es Saheli project. This project was designed to improve the coverage of the water needs of Nouakchott inhabitants by increasing the daily drinking water production from $65,000 \mathrm{~m}^{3} / \mathrm{d}$ in 2007 to $226,000 \mathrm{~m}^{3} / \mathrm{d}$ by 2030 , while guaranteeing good quality for this water. We will also discuss the approach and measures to be adopted to improve water management and distribution in the future.

\section{Equipment and methods}

\subsection{Equipment and methods used before the start-up of Aftout Es Saheli}

The research project was conducted in two phases. The first phase was conducted before Aftout Es Saheli, to characterize the water taken from the Idini well field. This work included household surveys in different neighborhoods and surveys of the drinking fountain operators. These surveys were completed with physico-chemical and bacteriological analyses performed along the entire distribution chain.

\subsubsection{Quality of the distributed water as perceived by the households}

The household surveys were organized around the following quality indicators: water supplied to the household, quality of the service supplied by the distribution operator, water availability, its price, and health problems (frequent diseases linked to water, completed by the mortality rate in the household or neighborhood). Two surveys were conducted in two different periods and three different Nouakchott neighborhoods; the first was performed in 2005 in the two neighborhoods of El Mina (poor neighborhood) and Tevragh-Zeina (affluent neighborhood), and the second survey was conducted in 2007 in the two poor neighborhoods of Sebkha and El Mina.

The population sample concerned by these two survey campaigns comprised 215 households, $75 \%$ of which lived in the two poor neighborhoods of El Mina and Sebkha. The population sample studied represented roughly $1 \%$ of the population of the three neighborhoods studied. The survey questionnaires included the following six criteria: Household/home typology(standard of living), level of household awareness concerning water quality and the environment, degree of accessibility to water and sanitation, purchase price for $1 \mathrm{~m}^{3}$ of water, water contamination and diseases related to contamination or sanitation, and the households' priorities. The surveys were conducted using the "face to face" method with representatives of each household, and the data was processed and the results managed using SPHINX statistical software.

\subsubsection{Detailed methods}

2.1.2.1. Mapping/cartography of the drinking fountains in Nouakchott. The mapping of the drinking fountains (BF) and the storage basins (BS) only concerned the El 
Mina and Sebkha neighborhoods, since there are no $\mathrm{BF}$ in Tevragh-Zeina. It was conducted using a ranking based on visual quality criteria for the condition of $30 \mathrm{BF}$ and basins. These $30 \mathrm{BF}$ were chosen based on their geographical, environmental, and sanitary representativeness in the two moughataas (neighborhoods) of El Mina and Sebkha, inhabited mainly by poor populations.

The visual ranking (rating) comprised three fundamental axes (the protection zone around the structure, the technical condition of the drinking fountain or basin, and the sanitary safety around the drinking fountain or basin). These axes were broken down into 25 criteria indicated below, and ranked with 50 points. The score given to each criterion varied from 0 to 2 depending on the condition of the structure ( 0 for poor condition, 1 for average condition, and 2 for good condition).

The seven criteria related to the first axis are: existence of a protection area beyond $6 \mathrm{~m}$, presence of donkeys nearby, presence of garbage and wandering animals, stagnant puddles of water, proximity of cesspits, proximity of vehicle repair garages, and proximity of unpaved roads.

The seven criteria related to the second axis are: quality of the piping between the network and the drinking fountain, location of the basin with respect to the ground, water tightness of the basin, water tightness of the cover and sides of the basin, quality of the underground piping of the Société Nationale de Distribution des Eaux (SNDE) [National Water Distribution Company] [4], presence of a pump, and imperviousness around the basin.

The eleven criteria related to the third axis are: use of protective equipment by the operator at the drinking fountain, use of protective equipment by the water distribution employee, manual drawing of water, water drawn with a pump, hose with tap at the end, maintenance of the pump, point to attach the hose and its tap above ground level, regular disinfection of the basin, regular disinfection of the reserve, control of the water quality in this reserve, and finally, control of the water quality in the basin.

2.1.2.2. Physico-chemical and bacteriological controls of the distributed water. The physico-chemical and bacteriological analyses were performed on the worst and the best drinking fountains (BF1 and BF2) selected with the method described above [5].

The samples were taken from the two BF chosen, one of which was the worst (BF1) and the other was the best (BF2), with a total of 18 samples per fountain (see Fig. 1, the map of sampling area in Nouakchott).
The samples were taken at all of the points along the water distribution chain, i.e. the drinking fountain reservoir or basin, the cart-driver's flask/drum (metal or plastic), the drum or the basin in the household, and finally, the household flask/jug filled directly from the drinking fountain.

The sampling protocol was as follows:

The physico-chemical analyses $(\mathrm{pH}$, electrical conductivity, temperature, static turbidity, salinity, $\mathrm{TH}$, and $\mathrm{NO}_{3}^{-}, \mathrm{NO}_{2}^{-}, \mathrm{Ca}^{2+}, \mathrm{Mg}^{2+}, \mathrm{Cl}^{-}, \mathrm{K}^{+}, \mathrm{Na}^{+}$, and $\mathrm{SO}_{4}^{2-}$ ) were conducted with volumetric dosages and UV-visible spectrophotometry, in accordance with the usual standards of the Association Française de la Normalisation (AFNOR) [French Association for Standardization]. They were identical to those performed previously [6]. The bacteriological analyses performed concerned total coliforms (TC) and Escherichia coli. These micro-organisms were identified and quantified using the Colilert ${ }^{\circledR}$ method, which included two types of tests: the qualitative Presence/Absence (P/A) test and the quantitative Quanti Tray test.

\subsection{Equipment and methods used after the start-up of Aftout Es Saheli}

The second phase of this research project concerned the impacts of the start-up of the Aftout Es Saheli project, and included expertise acquired through the study we conducted on site in 2011 on the entire water treatment and distribution chain, from its abstraction from the Senegal River to the tap in Nouakchott. It was accompanied by analyses performed under my supervision by students in the Water Management Master's program in Nouakchott, and in collaboration with the SNDE's Water Analysis Laboratory (see Fig. 1, the map of sampling area in Nouakchott).

With the Aftout Es Saheli installation in operation today, the situation is different, since it exploits surface water that therefore requires specific treatment, as it is more vulnerable to contamination risks and seasonal variations.

The water supply circuit of Nouakchott extracts water from the river. This installation is shown in the diagram in Fig. 2, and partly detailed in Figs. 3-6.

The hydraulic capacities of Aftout Es Saheli are considerable in comparison with the initial uptake of Idini.

The rated production capacities for the first phase of the Aftout Es Saheli project vary from 175,000 m³ $/ \mathrm{d}$ of raw water, to $170,000 \mathrm{~m}^{3} / \mathrm{d}$ of pretreated water, and $150,000 \mathrm{~m}^{3} / \mathrm{d}$ of treated water.

The second phase of the project should lead to a final flow rate of $263,000 \mathrm{~m}^{3} / \mathrm{d}$ of raw water $255,000 \mathrm{~m}^{3} /$ dof pretreated water, and $225,000 \mathrm{~m}^{3} / \mathrm{d}$ of treated water. 


\section{Map of sampling area in Nouakchott}

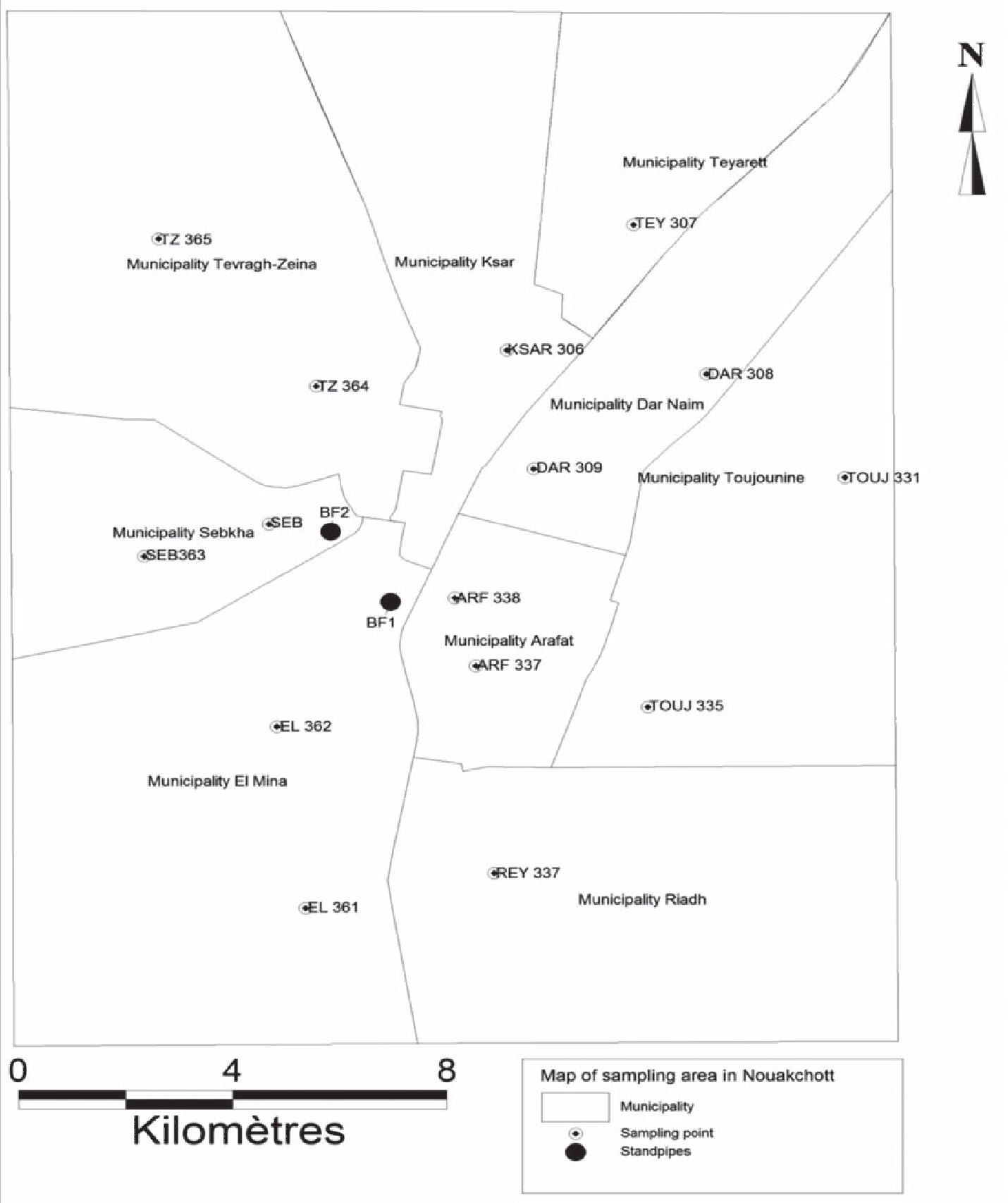

Fig. 1. The map of sampling area in Nouakchott.

\subsection{Hydraulic circuit information}

The raw water is transferred to Béni Nadji via two parallel pipes/conduits (diameter 1,100 mm, length $6 \mathrm{~km}$ ), and pressurized at the Aftout deep well pumping plant. The pretreated water is transferred from Béni Nadji to Nouakchott via a conduit/pipe (diameter 1,400 mm, length $170 \mathrm{~km}$ ). Once it arrives at PK17 (the water treatment plant located at $17 \mathrm{~km}$ from the city of Nouakchott (known as PK 17)), this water is stored in a large safety reserve with a 
capacity of $129,000 \mathrm{~m}^{3}$. At this point, the treatment involves filtration followed by disinfection, and the production capacity is forecast at $150,000 \mathrm{~m}^{3} /$ din the first phase. The capacities of the reserves have been designed to subsequently bring this production up to $225,000 \mathrm{~m}^{3} / \mathrm{d}$, corresponding to the needs forecasted for 2030 .

\subsection{Description of the Aftout treatment chain}

The purpose of the water treatment is to eliminate undesirable or toxic materials or transform them into harmless substances. To reach this objective, a certain number of processes are used, involving different techniques, from the intake to the arrival at the Nouakchott plant, as indicated in Figs. 2-6.

(1) Intake in the river: The raw water is drawn from the Senegal River using two pumps (flow rate $2.1 \mathrm{~m}^{3} / \mathrm{s}$ ). The water is then transported via two1100-mm conduits along a distance of $6 \mathrm{~km}$.

(2) Screening: The forecasted quantities to be pumped at the Aftout installation are $170,000 \mathrm{~m} 3 / \mathrm{d}$ by 2020 and 226,000 m3/d by 2030. The screening at the first treatment plant is shown in Fig. 3.

(3) Water treatment on the Béni Nadji site: Upon arrival, the raw water successively undergoes: prechlorination/coagulation/flocculation/clarification. Poly-electrolyte (M-6) thickening.

(4) Treatment plant at Nouakchott PK17 (17 km from Nouakchott): The clarified water passes through a quartz filtration system (model AQ azur V, shown in Fig. 5). The filtered water is finally disinfected (calcium hypochlorite) before being transported to the city via the Nouakchott plant.

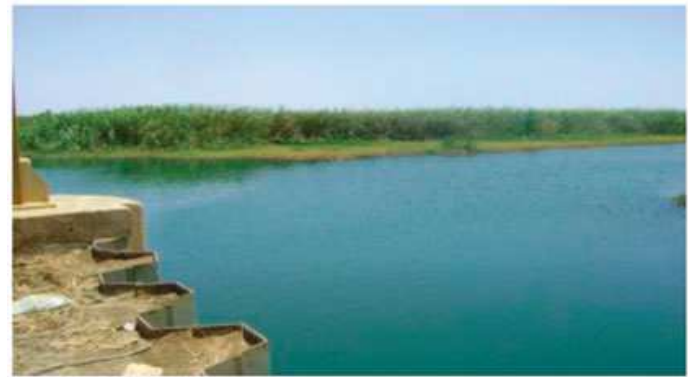

Fig. 3. The water intake from Aftout Es Saheli.

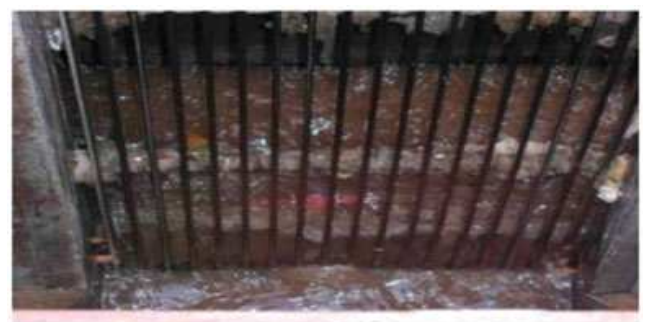

Fig. 4. Pretreatment site of Béni Nadji.

When it arrives at the main water tower site, the treated water is collected in the following structures in view of its distribution:

Three semi-underground reinforced concrete reservoirs, each with a capacity of $5,000 \mathrm{~m}^{3}$, and a water tower with a capacity of $1,000 \mathrm{~m}^{3}$.

The membrane filtration method was used to control the quality of the water from Aftout Es Saheli. The measurements were read on the day after the sampling. The sampling was performed in June 2011, and scrupulous attention was paid to the storage conditions.

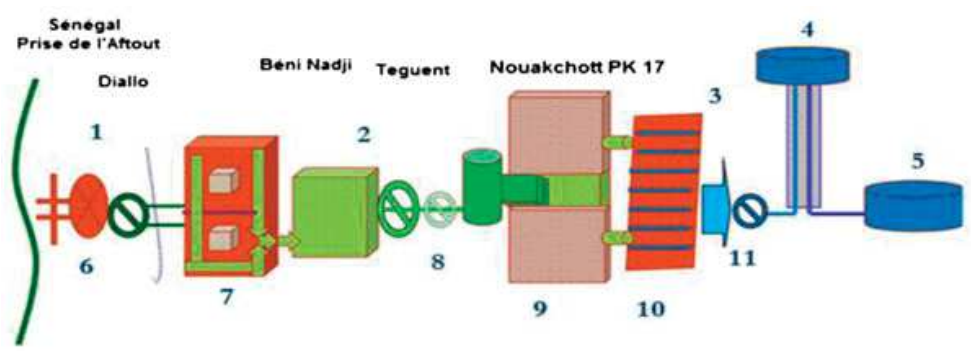

Fig. 2. General diagrammatic description of the Aftout Es Saheli water supply. (1) Raw water; (2) Clarified water; (3) Potable water; (4) Elevated tank $1,000 \mathrm{~m}^{3}$; (5) Water tower tank $5,000 \mathrm{~m}^{3}$; (6) Water intake and deep water pumping station; (7) Pretreatment and pumping; (8) Booster; (9) Reserves; (10) Filters; (11) Pumping. 


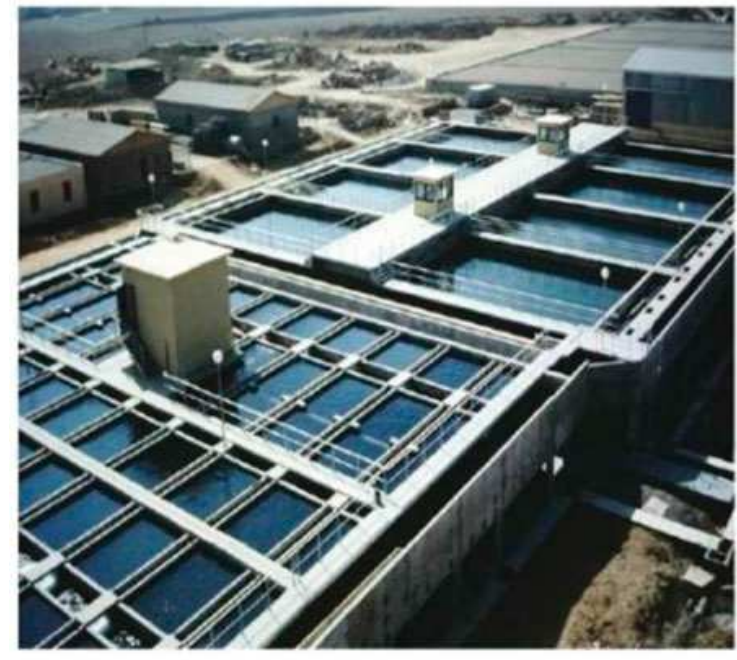

Fig. 5. Pulsa tube clarifier.

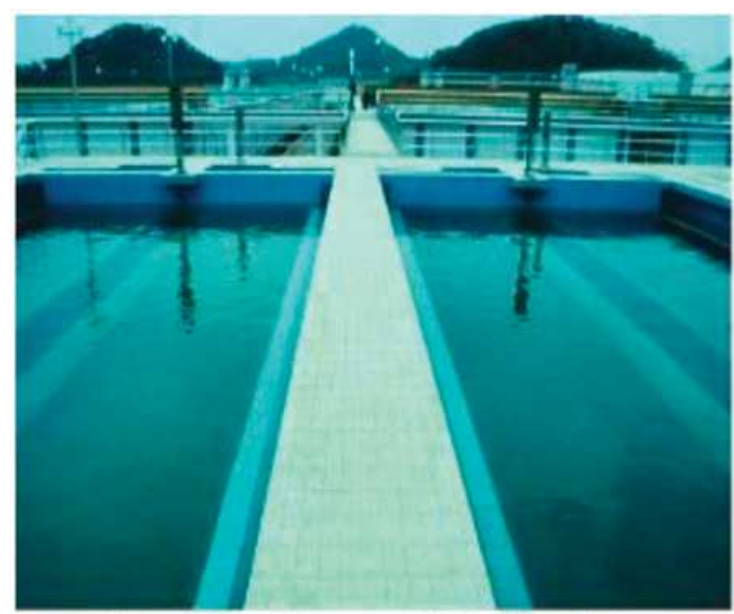

Vue de filtre Aquazur V double cellule

Fig. 6. Filters of 12 batteries.

\section{Results and discussion}

3.1. Results and discussions concerning the condition of the water distributed prior to the Aftout Es Saheli project

The results of the surveys concerning the perceived and supplied quality of the water distributed to the households are shown in Table 1. This table shows, via the criterion related to household typology, that half of the population in El Mina and Sebkha lived in precarious homes, and also that these were large families who were poor for the most part. It should also be indicated that the population in these underprivileged neighborhoods was not always aware of the impact of air quality on water and their environment and the risks of disease that could arise if the groundwater supplied to the city of Nouakchott was exposed to pollution [7]. The connection rates to the distribution and sanitation networks and the accessibility rate to water were very low for the two poor neighborhoods (El Mina and Sebkha). The percentages calculated for these three criteria were respectively 22,4 , and $35 \%$. Our survey also revealed that $85 \%$ of the households consumed less than $150 \mathrm{~L} / \mathrm{d}$, representing $15 \mathrm{~L} / \mathrm{d}$ per person on average. This per capita water consumption in the El Mina and Sebkha neighborhoods was thus roughly 10 times lower than the average European consumption. The connection rates to the distribution network were very low, and therefore the populations in these neighborhoods were mainly supplied by BF and cart-drivers.

A qualitative ranking of the condition and maintenance of the $\mathrm{BF}$ in the different neighborhoods studied led us to define a selection of certain BF whose water was then precisely analyzed.

The preexisting situation required that we first rank the $\mathrm{BF}$ to determine the best and worst $\mathrm{BF}$ in terms of quality. The results of this study are shown in Tables 2-4. In this drinking fountain ranking, we see that 13 out of 30 received relatively low scores, between 16 and 24 (below the overall ranking average of 25). The other $17 \mathrm{BF}$ follow the same trend, with higher scores varying between 25 and 36 .

We therefore chose the BF No. 2 and No. 29, since the two extreme BF (No. 1 and No. 30,-see Table 4) were not representative of the overall condition of the $\mathrm{BF}$ in Nouakchott (absence of cart-drivers, absence of a sufficient clientele, and even a missing tap on the drinking fountain No.30 since it is actually a storage basin disconnected from the network. These two BF are located in remote areas not often visited by water distributors.).

Of the two BF chosen, the best of the two (Saraghoulé) is located in the Sebkha neighborhood where most of the inhabitants have medium incomes.

The worst drinking fountain (Kebbet El Marbatt), named after the slaughterhouse near it in the El Mina neighborhood, is located in a slum (Kebba) whose population is extremely poor.

The sampling data and results of the bacteriological analyses for this first phase are summarized in Table 5 [8]. The summary of the analyses shows that for the two campaigns conducted in the two neighborhoods on the two $\mathrm{BF}$, we achieved $12 \mathrm{P} / \mathrm{A}$ results and 26 bacteriological count results (Quanti Tray), with the use of $38 \mathrm{P} / \mathrm{A}$ vials and 26 bottles of water. The sample results for the first part of this campaign 
Table 1

Results of the surveys on water quality before Aftout Es Saheli

\begin{tabular}{|c|c|c|}
\hline Criteria & Aspects & Results for the surveyed households \\
\hline \multirow[t]{3}{*}{ Household typology(standard of living) } & $\begin{array}{l}\text { Home/habitation made of } \\
\text { zinc or fabric }\end{array}$ & $40 \%$ \\
\hline & $\begin{array}{l}\text { Families with more than } 3 \\
\text { members }\end{array}$ & $81 \%$ \\
\hline & $\begin{array}{l}\text { Families with a monthly } \\
\text { income below } 40,000 \mathrm{UM} \\
(€ 130)\end{array}$ & $84 \%$ \\
\hline \multirow{4}{*}{$\begin{array}{l}\text { Level of household awareness } \\
\text { concerning water quality and the } \\
\text { environment }\end{array}$} & Importance of air quality & $76 \%$ \\
\hline & Importance of water quality & $88 \%$ \\
\hline & $\begin{array}{l}\text { Importance of protecting the } \\
\text { groundwater }\end{array}$ & $64 \%$ \\
\hline & $\begin{array}{l}\text { Impacts of wastewater } \\
\text { discharged from homes }\end{array}$ & $85 \%$ \\
\hline \multirow[t]{5}{*}{ Accessibility to water and sanitation } & $\begin{array}{l}\text { Rate of connection to the } \\
\text { distribution network }\end{array}$ & $22 \%$ \\
\hline & $\begin{array}{l}\text { Rate of connection to the } \\
\text { sanitation network }\end{array}$ & $4 \%$ \\
\hline & Rate of accessibility to water & $35 \%$ \\
\hline & $\begin{array}{l}\text { Quality of water pressure } \\
\text { (good) }\end{array}$ & $7 \%$ \\
\hline & $\begin{array}{l}\text { Households consuming less } \\
\text { than } 150 \mathrm{~L} / \mathrm{d}\end{array}$ & $85 \%$ \\
\hline \multirow[t]{2}{*}{ Purchase price of $1 \mathrm{~m}^{3}$ of water } & $\begin{array}{l}\text { Households that spent over } \\
1,000 \mathrm{UM}(€ 2.50) \text { per } \mathrm{m}^{3} \text { of } \\
\text { water }\end{array}$ & $63 \%$ \\
\hline & $\begin{array}{l}\text { Families who said that water } \\
\text { was very expensive }\end{array}$ & $95 \%$ \\
\hline \multirow[t]{4}{*}{$\begin{array}{l}\text { Water pollution and diseases linked to } \\
\text { water and sanitation }\end{array}$} & $\begin{array}{l}\text { Main causes of water } \\
\text { pollution }\end{array}$ & $\begin{array}{l}\text { Dust, sand, wind, animals, garbage, garages, } \\
\text { shops, waste and cesspits }\end{array}$ \\
\hline & $\begin{array}{l}\text { Most frequent diseases linked } \\
\text { to water and sanitation }\end{array}$ & Cholera, diarrhea and dysentery, malaria \\
\hline & $\begin{array}{l}\text { Main causes of mortality in } \\
\text { the neighborhoods }\end{array}$ & $\begin{array}{l}\text { Cholera, malaria, diarrhea, fever, hepatitis, } \\
\text { high blood pressure, cancer and traffic } \\
\text { accidents }\end{array}$ \\
\hline & Mortality rate and birth rate & High \\
\hline Priorities of the households & $\begin{array}{l}\text { The households wanting } \\
\text { priority }\end{array}$ & $\begin{array}{l}\text { Better accessibility to water (price, connection } \\
\text { to the city networks) }\end{array}$ \\
\hline
\end{tabular}

revealed that 10 out of 12 samples were contaminated with TC and Escherichia coli (EC).

The bacteriological results for the second part of the campaign were identical to those of the first and revealed significant total coliform contamination and a fairly low E. coli contamination. We also observed a systematic correlation between the TC and EC contamination for all of the nonconforming samples in the two campaigns conducted prior to Aftout Es Saheli.

In short, this highlights the strong correlation between the bacteriological contamination measured in our analyses and the following factors (observed in the survey and the sampling):
(1) Contamination of the water at the initial point of supply to the user at the different drinking fountain storage points due to handling of the equipment used to draw and distribute the water (manual drawing, hose connections lying on polluted ground, etc.).

(2) The lack of maintenance and disinfection of the BS and reserves, whose technical and sanitary quality is far from satisfactory (basin at ground level, insufficient sealing, etc.).

(3) The hygiene in the environment immediately surrounding the drinking fountain, with the 
Table 2

Survey summary: criteria and representativeness of the technical condition of the $30 \mathrm{BF}$ and basins studied

\begin{tabular}{|c|c|c|}
\hline Condition of the drinking fountain or water storage basin & Number & $\begin{array}{l}\text { Representativeness } \\
\text { percentage }(\%)\end{array}$ \\
\hline Number of permanent customers of the drinking fountain & $\begin{array}{l}16 \leq \mathrm{N} \text {. customers } \leq 50 \\
\text { (cart-drivers) }\end{array}$ & \\
\hline \multirow[t]{3}{*}{ Breakdown of the drinking fountains by technical typology } & Basin alone $=8$ & 27 \\
\hline & Basin $+\operatorname{pum} p=10$ & 33 \\
\hline & Basin + pump + reserve $=12$ & 40 \\
\hline \multirow[t]{3}{*}{ Water pressure at the drinking fountains } & Good $=7$ & 23 \\
\hline & Average $=12$ & 40 \\
\hline & Poor and Tank $=11$ & 37 \\
\hline Drinking fountains with technical problems & 7 & 23 \\
\hline $\begin{array}{l}\text { Proximity of donkeys, garbage, animal waste or stagnant } \\
\text { water }\end{array}$ & 26 & 81 \\
\hline Proximity of cesspits, garages or roads & 29 & 97 \\
\hline
\end{tabular}

Table 3

Survey summary: sanitary criteria for the 30 drinking fountains and basins studied

\begin{tabular}{|c|c|c|}
\hline Activity/Characteristic & Number of cases & Proportion and other observations \\
\hline Obvious health problem & $\begin{array}{l}\text { No health issues linked with water } \\
\text { were reported by the operators }\end{array}$ & $\begin{array}{l}\text { No health issues linked with the water } \\
\text { distribution, perhaps due to the lack of means } \\
\text { to verify whether the diseases propagated in } \\
\text { the neighborhoods were actually due to water } \\
\text { or other causes. }\end{array}$ \\
\hline $\begin{array}{l}\text { Drinking fountains with } \\
\text { daily or weekly } \\
\text { maintenance of their basin }\end{array}$ & $\begin{array}{l}\text { Only } 20 \text { of the drinking fountains } \\
\text { surveyed had any maintenance }\end{array}$ & $\begin{array}{l}\text { Of these, } 17 / 30 \text { received weekly maintenance } \\
\text { and } 3 / 30 \text { received maintenance every two } \\
\text { days. }\end{array}$ \\
\hline $\begin{array}{l}\text { Regular disinfection of the } \\
\text { basin with sodium } \\
\text { hypochlorite (Javel water) }\end{array}$ & $\begin{array}{l}11 \text { drinking fountains were regularly } \\
\text { disinfected }\end{array}$ & $11 / 30$ \\
\hline $\begin{array}{l}\text { Regular control of the quality } \\
\text { of the water distributed }\end{array}$ & $\begin{array}{l}\text { No drinking fountain was equipped } \\
\text { with a system to control the quality of } \\
\text { the water distributed }\end{array}$ & $0 / 30$ \\
\hline
\end{tabular}

Table 4

Drinking fountain classification using the scores attributed during the visual ranking

\begin{tabular}{lll}
\hline $\begin{array}{l}\text { Geographic location of the drinking } \\
\text { fountain }\end{array}$ & $\begin{array}{l}\text { Drinking fountain } \\
\text { score }\end{array}$ & $\begin{array}{l}\text { Ranking of the drinking fountain vs. all of the } \\
\text { fountains }\end{array}$ \\
\hline Sebkha 1 & 36 & 1 \\
Sebkha2 (Saragholé tap) & 34 & 2 \\
The other 26 drinking fountains & $19 \leq n \leq 27$ & $3-28$ \\
El Mina 16 (Kabet Elmarbat) & 17 & 29 \\
Sebkha 14 (Elbassera) & 16 & 30 \\
\hline
\end{tabular}

presence of animals, roads, markets, cesspits, mechanical garages, stations, and garbage heaps nearby.

(4) Transport by cart-drivers using donkeys and metal drums often in poor condition.

(5) Finally, the poor quality of storage in the households, with contaminated containers and poor preservation conditions.

One can also add to this list the lack of maintenance and disinfection of the transport and storage equipment, with no precautions taken to preserve the 
Table 5

Results of the first analysis campaign in 2007

\begin{tabular}{|c|c|c|c|c|c|}
\hline Drinking fountain & Sample number & $\mathrm{pH}$ & $\mathrm{CV}(\mathrm{ms} / \mathrm{cm})$ & $\mathrm{P} / \mathrm{A}$ & Fluorescence \\
\hline \multirow[t]{6}{*}{ BF No. 1} & No.01 & 8.1 & 680 & $\mathrm{P}$ & Positive \\
\hline & No.02 & 8.0 & 611 & $\mathrm{P}$ & Positive \\
\hline & No.03 & 8.0 & 679 & $\mathrm{P}$ & Positive \\
\hline & No.04 & 8.0 & 684 & $\mathrm{P}$ & Positive \\
\hline & No.05 & 8.0 & 693 & $\mathrm{P}$ & Positive \\
\hline & No.06 & 7.2 & 687 & $\mathrm{P}$ & Positive \\
\hline \multirow[t]{6}{*}{ BF No. 2} & No.07 & 7.9 & 675 & A & \\
\hline & No.08 & 7.9 & 681 & $\mathrm{P}$ & Positive \\
\hline & No.09 & 7.9 & 678 & $\mathrm{P}$ & Positive \\
\hline & No.10 & 8.0 & 681 & $\mathrm{P}$ & Positive \\
\hline & No.11 & 8.0 & 683 & $\mathrm{P}$ & Positive \\
\hline & No.12 & 7.9 & 674 & $\mathrm{~A}$ & Negative \\
\hline
\end{tabular}

Note: P/A: Presence/Absence.

quality of this water. Moreover, we observed that all of the results for the samples taken at the beginning of the distribution chain from BF2 were negative, and conversely, all of the results for the samples taken at the beginning of the distribution chain from BF1 were positive. This confirms the results of the visual assessment of the BF, which clearly indicated that the BF2 fountain was of superior quality and the BF1 of inferior quality.

Along the same lines, to reinforce the previous comment, we also observed that all of the samples taken from individual users' 20-L plastic jugs/flasks filled directly from $\mathrm{BF} 2$ had negative results. This inspires two additional comments: (1) if the available plastic jugs often used for this operation by the households are well maintained, they represent a minimal risk; and (2) the handling of the equipment used to distribute this water is often an additional source of contamination.

Most of the metal drums in poor apparent condition owned by the cart-drivers or households had samples containing a larger quantity of bacteria (TC and EC) than the other samples in the same distribution chain, indicating that there is a major risk linked to the use of these metal drums, some of which were previously used to store chemical products and pesticides that can cause contamination.

We also observed that the plastic drums/flasks used by the cart-drivers (of the OHCHR type: Office of the ex-High Commissioner for Human Rights and insertion) were well maintained and contained a smaller quantity of bacteria (TC and EC) than the other samples from the same distribution chain. This proves that it is necessary to recommend that users prefer this type of drums/flasks (with tap placed at the bottom). We also observed that the results of our physico-chemical analyses on the samples taken in both campaigns all complied with the WHO quality standards.

\subsection{Results after the commissioning of Aftout Es Saheli and their discussion}

\subsubsection{Evolution and diagnosis of the distribution infrastructures}

In recent years, there has been a slight increase in the number of inhabitants connected to the network, linked to the increase in population up to 2010. Indeed, the 238,920 inhabitants connected in 2004 increased to reach 332,690 in 2010.

3.2.1.1. Network pressure (weakness of the existing network). The water distribution is closely linked to the existing water network and its pressure. It should be noted that before the commissioning of Aftout Es Saheli, the pressure in the network was very low (between 0 and 1.4 bars at peak hours).

Currently, the pressure is quite high, generating numerous leaks and bursts throughout the network, as shown in Fig. 7 (below).

The existing network, for the most part quite dilapidated, is characterized by a very dense mesh structure, and nonoperational cut-off valves make sectorization increasingly difficult for maintenance operations and the search for leaks.

The network is composed of $7 \%$ gray cast iron and carbon steel pipes, 80\% PVC pipes, and 13\% ductile cast iron pipes. The carbon steel and gray cast iron pipes are the oldest and have the most leakage, followed by the PVC pipes that have proven to be the most fragile due to adhesion problems at the joints, 


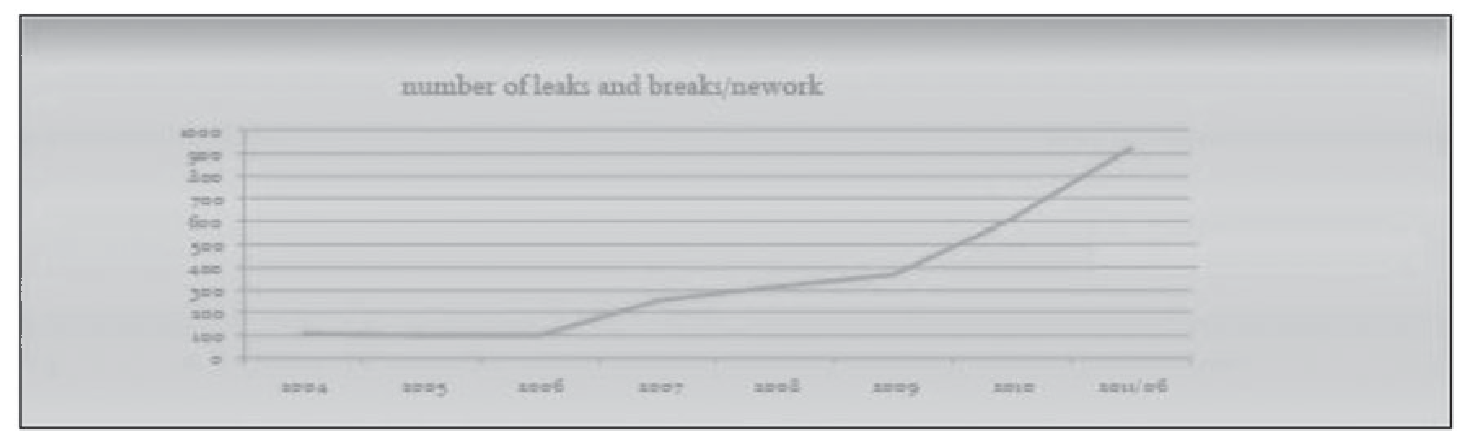

Fig. 7. Distribution network situation vs. network pressure.

which do not withstand high temperatures, and also to the trenches, often very shallow, that transfer surface loads to the pipes (truck and automobile traffic).

The government program plans for a distribution network in conformity with the distribution network master plan (SNDE, 2010), totally composed of polyethylene. This material offers several advantages, such as:

(1) Flexible installation;

(2) Assembly by welding (preventing infiltration);

(3) Resistance to soil aggressiveness.

3.2.1.2. Linear distribution of the network per moughataa. The layout in $\mathrm{km}$ of the distribution network per moughataa is shown in kilometers (Table 6), highlighting the unequal distribution of the network, especially when comparing the city center with the outlying peripheral areas.

\subsubsection{Results of the water analyses}

The analyses performed during the second phase of our research project were focused on the distribution network of which physico-chemical results are shown in Table 7 . Since we had confirmed that the source, i.e. the water tower and PK17 in Nouakchott

Table 6

Linear distribution of the network per Moughataa (in km)

\begin{tabular}{ll}
\hline Tevragh-Zeina & 242 \\
Ksar & 187 \\
Teyarett & 99 \\
Toujounine & 66 \\
Dar Naim & 121 \\
Arafat and Riyad & 220 \\
El Mina & 88 \\
Sebkha & 77 \\
\hline
\end{tabular}

(filtered outlet) was not contaminated, we could therefore advance that the origin of the nonconformities observed at certain very limited points was not linked to the intrinsic quality of the water but rather to an external cause (pipe leakage, proximity of the sanitation network, etc.).

As a partial conclusion, we confirm that the water from the Aftout installation is of good quality, based on all of the samples analyzed, with the exception of a few minor cases of samples in which a limited quantity of coliforms were observed below the limits of potability standards. This can only be caused by the distribution network, due to the dilapidated state of the pipes and the pressure of the water coming from Aftout Es Saheli.

\subsubsection{Summary of the evolution of the water distribution system in Nouakchott after the commissioning of Aftout Es Saheli}

The physico-chemical analyses of the water conducted after the commissioning of Aftout Es Saheli between April and June 2011in the framework of our study and other studies on site $[9,10]$ indicate that all of the physico-chemical and bacteriological parameters of the samples taken from the different moughataas and analyzed comply with WHO standards. However, the presence of coliforms was sometimes observed, but at a rate below the limits of the standard. We should add that in the context of our study, the total number of coliforms has shown a downward trend. In May 2010, we observed a remarkable number of TC, whereas in June 2011 this quantity had significantly decreased.

Consequently, we can state that despite the dilapidated state of the water distribution network in Nouakchott, the quality of the water from Aftout Es Saheli is constantly improving, and the current 
Table 7

Results of physico-chemical analyzes in June 2011

\begin{tabular}{|c|c|c|c|c|c|c|c|c|c|c|c|}
\hline Code & $\mathrm{pH}$ & TDS & Turb & $\mathrm{CV}$ & $\mathrm{KMNO}_{4}^{-}$ & $\mathrm{NO}_{3}^{-}$ & $\mathrm{NH}_{4}^{+}$ & Fer & $\mathrm{Al}$ & TA & TAC \\
\hline Ksar 306 & 8.42 & 55 & $<1$ & 88.7 & - & 1.5 & 0.01 & 0.03 & 0 & 0 & 1.1 \\
\hline TEY 307 & 8.26 & 55 & $<1$ & 86.4 & - & 1.8 & 0 & 0.02 & 0 & 0 & 0.08 \\
\hline $\begin{array}{c}\text { DAR } \\
308\end{array}$ & 7.12 & 280 & $<1$ & 448 & - & 0.9 & 0 & 0.05 & 0.013 & 0 & 2.9 \\
\hline $\begin{array}{r}\text { DAR } \\
309\end{array}$ & 7.05 & 270 & $<1$ & 459 & - & 0.2 & 0 & 0.06 & 0.022 & 0 & 2.5 \\
\hline $\begin{array}{r}\text { TOUJ } \\
331\end{array}$ & 7.12 & 285 & $<1$ & 384 & 1.1 & 2.5 & 0.11 & 0.18 & 0 & 0 & 1.1 \\
\hline $\begin{array}{r}\text { TOUJ } \\
335\end{array}$ & 7.09 & 285 & $<1$ & 394 & 1 & 3.9 & 0.011 & 0.17 & 0.015 & 0 & 1.7 \\
\hline REY 337 & 8.51 & 60 & $<1$ & 84.4 & 1.2 & 8.4 & 0.01 & 0.03 & 0.011 & 0 & 0.7 \\
\hline ARF 337 & 7.05 & 285 & $<1$ & 400 & 1.2 & 4.3 & 0.11 & 0.15 & 0 & 0 & 1.3 \\
\hline ARF 338 & 7.17 & 285 & $<1$ & 394 & 1.5 & 3.8 & 0.13 & 0.08 & 0.022 & 0 & 1.9 \\
\hline EL 361 & 8.46 & 61 & $<1$ & 93.1 & 0.6 & 3.3 & 0 & 0.03 & 0 & 0 & 1.4 \\
\hline EL 362 & 8.21 & 59 & $<1$ & 90.4 & 0.2 & 3.4 & 0 & 0.05 & 0.011 & 0 & 1.6 \\
\hline SEB 363 & 8.04 & 59 & $<1$ & 91.5 & 0.9 & 6.5 & 0 & 0.02 & 0.013 & 0 & 1.3 \\
\hline SEB & 8.53 & 62 & $<1$ & 97.4 & 0.9 & 3.9 & 0 & - & - & 0 & 1.5 \\
\hline TZ 364 & 8.3 & 59 & $<1$ & 97.3 & - & 0.6 & 0 & 0.07 & 0 & 0 & - \\
\hline TZ 365 & 8.57 & 59 & $<1$ & 89.6 & 0.6 & 4.8 & 0 & 0.04 & 0 & 0 & 1.2 \\
\hline
\end{tabular}

Note: Sampling date: June 2011 Storage conditions: respected.

Ksar 306, sampling point: municipality of Ksar, TEY 307, sampling point: municipality of Teyarett, DAR 308, 309, sampling point: municipality of Dar Naim, TOUJ 331, 335, sampling point: municipality of Toujounine, ARF 337, 338, sampling point: municipality of Arafat, REY 337, sampling point: municipality of Riadh, EL 361-362, sampling point: municipality of El Mina, SEB 363, SEB, sampling point: municipality of Sebkha, and TZ 364,365, sampling point: municipality of Tevragh-Zeina.

The results of the above table for the values of the physico-chemical analyses carried out on the following parameters: $\mathrm{pH}, \mathrm{CV}, \mathrm{T}\left({ }^{\circ} \mathrm{C}\right)$, TDS, $\mathrm{NO}_{3}^{-}, \mathrm{NO}_{2}, \mathrm{Fe}, \mathrm{Al}, \mathrm{NH}_{4}^{+}, \mathrm{TA}, \mathrm{TAC}$, and $\mathrm{KMnO}_{4}$ conform to the standards published by WHO.

coverage of the water needs of Nouakchott's inhabitants is fairly good.

It is therefore possible to make water of excellent quality accessible in Nouakchott by installing a new distribution network capable of withstanding the pressure of the water from Aftout Es Saheli. To solve this major problem, the Mauritanian government has launched a call for tender, which was well advanced at the date of our study.

3.2.3.1. List of the distribution system issues or points to be improved in the short and medium term.

(1) Absence of an updated map;

(2) Condition of the cut-off valves, often placed underneath the paved road;

(3) Fraudulent connections;

(4) Excessively dense mesh between primary and secondary networks, leading to flows in different directions;

(5) Lack of maintenance of pipe equipment on lines (air vents, drainage valves);

(6) Lack of a systematic maintenance program for the ordinary network pipe equipment, such as valves, meters, air vents;
(7) A large number of leaks at the connections, especially at the fittings, pipe rings, taps, etc.;

(8) Dilapidated state of the network and corrosion, especially in Sebkha and El Mina due to aggressive soil and the type of materials used.

In general

(1) A network unable to distribute all of the treated water;

(2) Overall network efficiency is low; (high leakage rate) the number of leaks per year increased from 370 bursts and leaks in the network in 2009 to over 700 bursts and leaks in the network in 2011, and from 485 leaks at the connections in 2009 to over 950 leaks, i.e. almost double, one year after the start-up of the Aftout Es Saheli project;

(3) Distribution coverage must still be generalized by installing new networks all over the city, especially in the peripheral areas, despite the significant improvement of this coverage since the start-up of Aftout Es Saheli in many fairly 
remote areas of the peripheral moughataas previously serviced only by the cart-driver resellers, which represents a certain degree of progress that must be further reinforced.

\section{Discussions and conclusions}

The overall situation of the water distribution system in Nouakchott prior to Aftout Es Saheli was highly preoccupying, from both a quantitative and qualitative standpoint.

At that time, there was a growing imbalance between supply and demand. Indeed, the annual production had not been significantly improved since 2000, and was below 50,000 $\mathrm{m}^{3} / \mathrm{d}$ (of which only $32,000 \mathrm{~m}^{3} / \mathrm{d}$ were invoiced) in 2005 , although the population had increased spectacularly; in 2000, the population was at about 560,000, and in 2005 it had reached 750,000 inhabitants (i.e. an increase of $1 / 3$ over a 5-year period).

It should also be added that the production prior to Aftout Es Saheli was roughly $65,000 \mathrm{~m}^{3} / \mathrm{d}$.

At that time, the water distribution system was still unreliable and was based on a fragile network (BF, cart-drivers, etc.). In the two peripheral neighborhoods studied, $89 \%$ of the households were not connected to the network according to our survey results. As for the evaluation of the cost generated by this unequal fresh water distribution, the statistical results (Agence de Développement Urbain en Mauritanie (ADU) [11] and the household surveys showed that the Nouakchott inhabitants connected to the network at that time represented a small minority who paid a price for water much lower than that paid by the unconnected inhabitants, most of whom lived in the city's underprivileged neighborhoods.

From the qualitative standpoint, the results of the analyses showed that the physico-chemical quality of the water in the distribution networks and at the $\mathrm{BF}$ was compliant with WHO standards; however, the BF were contaminated on a bacteriological level.

Indeed, the hygiene conditions around the public distribution points in Nouakchott were unreliable and often unsanitary. For example, water was often drawn at the ground level, from vertical cement tanks that separated the dirty ground from the underground distribution pipes.

In Nouakchott, the sanitation network existed essentially in two neighborhoods, while the remaining inhabitants discharged wastewater in front of their homes into a basin or a well, causing contamination of the water distribution points (according to our household surveys, nearly $99 \%$ had recourse to this unsanitary wastewater disposal).

There was a very strong correlation between water consumption and the standard of living. The low level of supply and therefore of consumption has been a contributing factor to the fragility of the social and economic development achieved up until now.

The following can be said about the Aftout Es Saheli project, commissioned in October 2010:

(1) It is a sustainable project: The quantity of water drawn from the river is small in comparison with the river's flow rate $\left(170,000 \mathrm{~m}^{3} / \mathrm{d}\right.$ by 2020 , and $226,000 \mathrm{~m}^{3} / \mathrm{d}$ by 2030 , for a very high river flow rate);

(2) It is compatible with the water usage of the neighboring countries (Senegal, Mali, etc.);

(3) It is compatible with the evolution of the population of Nouakchott up to 2030;

(4) It has clearly improved the water supply to Nouakchott inhabitants, with better quality supplied to the customers, and has had a significant influence on reducing the costs of the water distributed via the high-risk informal system (cart-drivers/resellers, tanks, etc.).

Nevertheless, its operation has posed some problems for the SNDE in the city of Nouakchott, including:

Weaknesses of the current network:

(1) Global problem of surface water fragility;

(2) Unequal and insufficient coverage of certain peripheral moughataas;

(3) Significant and more frequent leaks, lack of maintenance personnel at the SNDE sufficiently trained in this field;

(4) Lack of technical equipment and adequate training for the personnel in charge of controlling water quality in the SNDE Water Analysis Lab.

The improvement measures can be divided into two categories. The first includes those that are urgent and are being carried out by the public authorities in the short term, and the second concerns the measures that must be implemented in the medium and long term. 
4.1. Strong points or solutions implemented or being implemented in the short term by the public authorities (SNDE:)

(1) Removal of the bottlenecks in the distribution network;

(2) Organization of a supply to the unconnected neighborhoods using tank trucks (adopted for their housing areas);

(3) Multiplication of $\mathrm{BF}$ and water points in the underprivileged neighborhoods;

(4) Systematic repair of the leaks at connections and along the network (multiplication of repair teams);

(5) Commissioning of the Toujounine plant making it possible to cover all of the usages in this area thanks to good pressure (Toujounine, Dar Naim, etc.);

(6) Installation of a polyethylene high density (PEHD) network in Toujounine and a portion of Dar Naim;

(7) Commissioning of the Teyarett plant very soon and partial rehabilitation of its distribution network.

\subsection{Proposals for medium- and long-term improvements}

(1) Acceleration of the installation of the future distribution network in the city;

(2) Activation of the chlorine injection plants and an increase in their number;

(3) Reinforcement of the human and material resources in the SNDE's water quality control laboratory;

(4) Professional training in quality control for SNDE laboratory personnel;

(5) Creation and equipment of several additional water quality control laboratories in Nouakchott to meet user and industry needs;

(6) Supervision in the medium term of quality control, especially for the informal water distribution network (BF, cart-drivers, BS, etc.). This informal network still exists, but should disappear in the long term;

(7) It is urgent to improve the individual sanitation means in the underprivileged neighborhoods. This requires either creating a generalized, reliable sanitation network for the entire city to prevent the contamination by wastewater of the distributed drinking water or to use less expensive and more accessible systems in each moughataa, such as the installation of wastewater treatment units using macrophytes (aquatic plants);

(8) A substantial reinforcement of the household waste collection and treatment system in the city and the creation of a storm water discharge network, especially in the areas connected to the sanitation network and in the neighborhoods at risk. These measures should be rapidly envisaged in order to limit the propagation of certain epidemics linked to water stagnation such as cholera and malaria.

\section{References}

[1] M.Y. Ould El Joud, Gestion durable des ressources en eau du bassin Sud-Ouest mauritanien, géologie, hydrogéologie et modélisations [Sustainable Management of Water Resources in The South-West Mauritanian Basin, Geology, Hydrogeology and Modeling], $\mathrm{PhD}$ thesis, Presented at the University of Nice Sophia Antipolis, Nice, France, 1998.

[2] E. Balloff and DHA (Direction de l'Hydraulique et de l'Assainissement) [Directorate of Water and Sanitation], Note de synthèse concernant les different scenarios d'approvisionnement de la ville de Nouakchott et des zones urbaines voisines [Summary Reports Concerning the Different Scenarios for the Water Supply of the City of Nouakchott and its Surrounding Urban Area], (Directorate of Water and Sanitation), Nouakchott, Mauritania, 2000 and 2001.

[3] A. Seureca, Rapport sur la mise en production du champ captant de Ténadi: avenant $\mathrm{n}^{\circ} 1$, simulation hydrogéologique du champ captant d'Idini [Report on the Production of Tenadi Capturing Field: Endorsement No. 1, Hydro-Geological Simulation of the Well Field of Idini], Nouakchott Drinking Water Supply Project, Nouakchott, Mauritania, 1997.

[4] National Water Distribution Company (SNDE), Rapport sur la situation des systèmes d'alimentation en eau potable à Nouakchott [Report on the situation of drinking water supply systems in Nouakchott], 2010.

[5] I.A. Babah, Développement du système de qualité environnementale et sanitaire de la distribution de l'eau potable à Nouakchott (Mauritanie) [Development of Environmental Quality and Health System for the Distribution of Drinking Water in Nouakchott (Mauritania)]. PhD thesis, Presented at the University of Savoie, Chambéry, France, 2007.

[6] M. Ould Ahmed Djegue, La qualité des eaux d'alimentation dans les quartiers à forte concentration de la ville de Nouakchott (Mauritanie) [The Quality of the Feed Water in Neighborhoods with High Concentrations of Nouakchott (Mauritania)], PhD thesis, Presented at the University of Nice Sophia Antipolis, Nice, France, 2000.

[7] C. Haslay, H. Leclerc, Microbiologie des eaux d'alimentation, technique et documentation [Microbiology of Water Supply, Technique and Documentation], Lavoisier, Paris, France, 1993. 
[8] I.A. Babah, M.F. Deida, G. Blake, D. Froelich, Fresh water distribution problematic in Nouakchott, Science Direct, Procedia Eng. 33 (2012) 321-329.

[9] C. Mint Mohamed Khouna, Z. Mint Sidi, Evolution de la qualité de l'eau potable à Nouakchott [Evolution of the Quality of Drinking Water in Nouakchottl, MGE Master's degree thesis, presented at the SNDE, FST, University of Nouakchott, Mauritania, 2011.

[10] F. Mint Sidi El Kheir, K. Mint Ahmedou, Système de distribution de l'eau potable à Nouakchott [Distribution System of Drinking Water in Nouakchott],
Master's degree thesis, Presented at the SNDE, FST, University of Nouakchott, Mauritania, 2011.

[11] Agence de Développement Urbain en Mauritanie (ADU) [Urban Development Agency in Mauritania], Acte de l'atelier relatif à la gestion des bornes fontaines dans la commune d'El Mina, organisé par l'ADU [Proceedings from the Workshop on the Management of the Drinking Fountains in the Municipality of El Mina Organized by the ADU], Nouakchott, Mauritania, 2003. 